\title{
Erratum to: Benign chondroid syringoma (mixed tumor of skin) on the flank with satellites: case report and literature review
}

\author{
U. Wollina $\cdot$ U. Sturm $\cdot$ J. Schönlebe
}

Published online: 24 October 2014

(C) Springer-Verlag Wien 2014

\section{Erratum to: Wien Med Wochenschr (2014) 164:377-380 DOI 10.1007/s10354-014-0302-0}

Unfortunately, figure legend of Fig. 2 is incorrect. Please find the correct one below.
The online version of the original article can be found under doi:http://dx.doi.org/10.1007/s10354-014-0302-0

\section{Prof. Dr. med. U. Wollina, MD $(\square)$}

Department of Dermatology and Allergology,

Academic Teaching Hospital Dresden-Friedrichstadt,

Friedrichstrasse 41

01067 Dresden, Germany

e-mail: wollina-uw@khdf.de

\section{U. Sturm, MD}

Practice for Pathology,

Steubener Str. 12,

01279 Dresden, Germany

J. Schönlebe, MD

Institute of Pathology,

Academic Teaching Hospital Dresden-Friedrichstadt,

Friedrichstrasse 41,

01067 Dresden, Germany
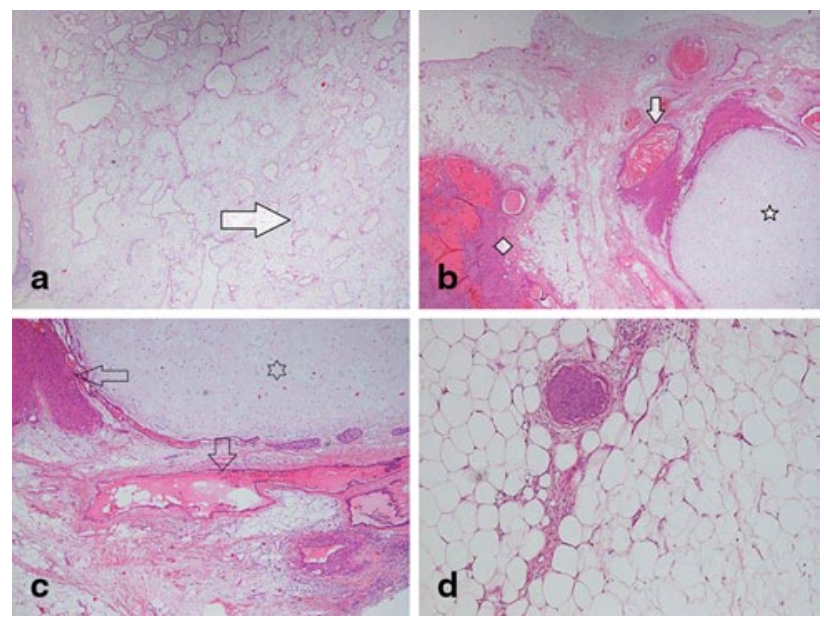

Fig. 2 Mixed tumor of skin. Histopathology (hematoxylineosin). a Overview $(\times 2)$ demonstrating syringoma-like spaces (arrow) embedded in a sclerotic stroma. b Overview $(\times 2)$ demonstrating a mixture of solid basaloid areas (square), chondroid areas (star), and keratin cysts (arrow). c Detail $(\times 4)$ presenting solid areas (horizontal arrow), clear cells areas (vertical arrow), and chondroid cells within a chondroid stroma (star). d Detail $(\times 10)$ demonstrating a small basaloid Island in the adipose tissue stroma 